\title{
Perceptions of Organizational Politics: Should Teleworkers Beware?
}

\author{
By \\ Gretchen A Decker, University of Missouri, St. Louis \\ Jaime E Peters, University of Missouri, St. Louis \\ Andrew Thomas, University of Missouri, St. Louis \\ Elizabeth Boyle, University of Missouri, St. Louis \\ William P Butler, University of Missouri, St. Louis
}

$\mathrm{D}$ rawing from telework and organizational politics literature, this case study of a sales team at Midwest Global Manufacturing (MGM) reviews the perception of organizational politics (POP) and whether office-based employees and teleworkers perceive politics differently. (For summary of current literature on POP see Ferris et al., 2019). The researchers expected teleworkers to perceive organizational politics differently, since the teleworker is remote and misses daily face-to-face interactions. However, after a thorough examination of the case study data, we concluded that in the context of MGM, there was not a difference in POP between office-based employees and teleworkers.

This study is an important contribution because there are limited studies on the difference in POP in work modalities in the politics and teleworking literature (e.g., Elron \& Vigoda-Gadot, 2006). Yet, many companies have teleworking policies and a mix of teleworkers and office-based employees. Managers and employees alike may benefit from considering this study to ensure that both teleworkers and office-based workers can universally achieve a positive perception when utilizing the political system.

Keywords: Telework, Teleworking Intensity, Teleworker, Professional Isolation, Organizational Politics, Perceptions of Organizational Politics

Copyright @ 2020, Gretchen A Decker, Jaime E Peters, Andrew Thomas, Elizabeth Boyle, William P Butler. This article is published under a Creative Commons BY-NC license. Permission is granted to copy and distribute this article for non-commercial purposes, in both printed and electronic formats 
Teleworking, defined as the use of information and communication technologies so employees can perform work outside of an established corporation's home office (Bélanger, Watson-Manheim, \& Swan, 2013), has seen steady adoption over the last fifty years and has experienced a boom in the previous decade with a reported $43 \%$ of employees using this benefit (Gallup, 2016). As with any workplace benefit, there are advantages and disadvantages for both the employee and employer. Several studies report that teleworkers are more productive than office-based employees (Bloom et al., 2014; Harker Martin \& MacDonnell, 2012). However, other studies report the dark side of teleworking, which includes relational impoverishment for employees such as professional isolation and social isolation (Golden, Beiga, \& Dino, 2008) which reduced professional development (Cooper \& Kurland, 2002). In addition, studies have found that employers suffer as knowledge transfer can be impaired with remote employees (Taskin \& Bridoux, 2010).

Regardless of physical work location, the success of a business, a team, or an individual often depends on the ability to "get it done"; a situation that can often be frustrated by formal

processes developed at the corporate level. To overcome these roadblocks, employees may engage in organizational politics, defined as informal systems where individuals use networks and connections to obtain results and outcomes (Butler, Decker, Peters, Thomas, \& Merritt, 2019; Cropanzano, Howes, Grandey, \& Toth, 1997; Ferris et al., 2019). Employees perceive political acts as negative or positive (Fedor, Maslyn, Farmer, \& Bettenhausen, 2008). A recent study, limited to office-based employees, found that the number of individuals benefiting from the act as well as the overall transparency drives the valence of perceptions (Butler et al., 2019). To date, there has been limited research conducted to understand how perceptions may vary for teleworkers and in-office employees (Ferris et al., 2019, p. 319):

Remote-work arrangements and the assemblage of virtual work teams who might never meet in person have the potential to alter much of what we know about building and leveraging influence at work. Research is needed to understand in what ways politics exists and differs for employees in virtual settings.

This gap in the literature presents a two-fold business problem. First, as telework rates rise, do managers and organizations need to make adjustments to ensure employees' work locations do not alter their perceptions of organizational politics? Second, do office-based employees and teleworkers need to change their approach when using informal political systems to ensure co-workers experience positive perceptions?

To address these business problems, we sought to understand whether the work location (i.e., office-based or telework) influenced the employee's perceptions of organizational politics. We employed a case-study methodology to explore this question. We interviewed seven team members (two teleworkers, three office-based employees, and twopart telework/part office-based) from a sales team at Midwest Global Manufacturing (MGM) and their president to understand their perceptions.

\section{Review of Research and Theory}

\section{The Benefits and Drawbacks of Tele- work}

The majority of telework literature has focused on the outcomes associated with this work arrangement, mainly categorized as benefits and drawbacks. Flexible work programs, such as telework, have numerous advantages. The organization receives benefits from increased productivity, reduced facility costs, and a competitive edge when attracting human capital (Bloom et al., 2014; Breaugh \& Farabee, 2012). Furthermore, employees also reap benefits. For example, Gajendran and Harrison (2007) observed that teleworking improves the work-family relationship, job satisfaction, turnover intentions, and role stress.

Telework also has disadvantages at both the organizational and individual levels. From an organizational point of view, managers have a harder time monitoring teleworkers (Felstead, Jewson, Phizacklea, \& Walters, 2002) as many managers feel they lack the performance management tools needed to effectively monitor teleworkers (Kaplan, Engelsted, Lei, \& Lockwood, 2018). Telework can also lead to professional isolation resulting in career consequences such as fewer promotion opportunities, lower pay and less recognition, and inability to learn from colleagues (Cooper \& Kurland, 2002; Golden et al., 2008). Several other studies have highlighted employee knowledge transfer as a significant disadvantage (Apgar IV, 1998; Boell, Cecez-Kecmanovic, \& Campbell, 2016; Gorman, 2017; Miller \& Rampell, 2013). Companies such as IBM, Yahoo, and American Express touted the benefits of teleworking and launched robust programs yet pulled back their teleworking policies over time due to knowledge transfer concerns. In a Yahoo internal memo, a human 
resources director stated, "Some of the best decisions and insights come from hallway and cafeteria discussions, meeting new people and impromptu team meetings. Speed and quality are often sacrificed when we work from home" (Miller \& Rampell, 2013, p. 1).

However, there is good news. Companies and individuals can implement strategies to help offset some of the teleworking disadvantages. Turetken, Jain, Quesenberry, and Ngwenyama (2010) found that rich communication tools reduce the link between telework and professional isolation. Additionally, telework is not an all or nothing proposition. The amount of time spent teleworking can vary significantly, from five days a week to just one day a month. This concept is called telework intensity (Fay \& Kline, 2011). In the literature, telework intensity is defined as high when an employee is a teleworker more than three days a week and low when telework is less than three days a week (Golden et al., 2008). A low-intensity teleworker often achieves many of the benefits of telework, but it can also limit the negative impacts (Gajendran \& Harrison, 2007; Golden, 2007; Golden et al., 2008).

\section{Organizational Pol- itics}

While most organizations have a legitimate formal system for defining ways of working, all organizations also have informal political systems, known in literature as organizational politics, where individuals use networks and connections to achieve results (Butler et al., 2019). The construct of organizational politics has evolved, from one that companies would want to squash to one they may tolerate or even exploit. Historically, organizational politics was portrayed in a negative light; however, more recently, other scholars describe politics as a neutral phenomenon. The most quoted definition in the literature is from Mintzberg's (1985) work: "individual or group behavior that is informal, ostensibly parochial, typically divisive, and above all in a technical sense, illegitimate - sanctioned neither by formal authority, accepted ideology, nor certified expertise" (p. 172). Over the last 30 years, scholars have developed more neutral definitions. Ferris et al. (2019) define politics as "actively managing the meaning of situations in ways that result in the elicitation of desired actions and outcomes" (p. 301). Cropanzano et al. (1997) provide a two-fold definition of politics: "an influence process that is exercised within work settings" and "behavior that is strategically designed to maximize short-term or long-term self-interest" (p. 160-161). The commonality across definitions is the use of an informal process to influence others to obtain outcomes.

Ferris, Russ, and Fandt (1989) created the Perception of Organizational Politics (POP) construct. The team sought to understand what drives an organization to be political and what causes an employee to perceive the work environment as political. Kacmar \& Ferris (1991) developed the first POP scale to measure perceptions at the individual level, but this scale relied on the old negatively skewed definition of organizational politics. Subsequently, Fedor, Maslyn, Farmer \& Bettenhausen (2008) found that both negative and positive perceptions were distinct constructs and developed a new POP scale that measures both valences.

Recognizing that POP could be negative or positive, Butler et al. (2019) set out to understand the drivers behind perceptions. In a study of office-based employees, it was discovered that the number of individuals benefiting from the act, as well as the overall transparency, drives the valence of perceptions (Butler et al., 2019). This model explains that perceptions of political acts are positive when the political event is transparent with altruistic intentions. The theory also finds that the greater the number of beneficiaries, the higher the likelihood of positive perception. Alternatively, if an individual receives the benefit from a political act, perceptions are more likely to be negative. However, it is crucial to note that an individual may be able to overcome a negative perception in a transparent process. Conversely, if a political act benefits a group with a process that lacks transparency, the chance of a negative perception increases.

\section{Teleworkers and Organizational Politics}

Literature supports that workers rely on organizational politics to trade favors, create networks, and use back channels to achieve outcomes. It is also clear that POP can fluctuate based on the events surrounding the outcome. However, the politics literature is focused on office-based workers and is sparse on telecommuting relationships. The lack of research begs the question: If a teleworker lacks the same opportunities for visibility, building relationships, and knowledge transfer as an office-based employee, do they perceive organizational politics differently than their office-based counterparts?

\section{The Case}

The case leveraged a sales team from a division of an electronics manufacturing company, identified as Midwest Global Manufacturing (MGM). MGM is a 


\section{Methodology}

This study emerged over a three-month period using the case study methodology. Yin (2018) defines a case study as, "an empirical method that investigates a contemporary phenomenon (the "case") in depth and within its real-world context, especially when the boundaries between phenomenon and context may not be clearly evident" (p.15). The research team used an interpretive approach. Myers (2019) states, "Interpretive researchers assume that access to reality (given or socially constructed) is only through social constructions such as language, consciousness, shared meanings, and instruments" (p. 39). Since the research team was searching for the MGM team member's perceptions of common political events, it was important to understand how perceptions were formed and political events were interpreted.

A single case study was designed for two reasons. First, the authors sought a critical case where the context was controlled (e.g., same culture, same supervisor, same policies, same procedures and critical events), in a team that contained both teleworkers and office-based employees. Therefore, all participants worked in sales, for the same president, in the same culture. Controlling for context helped the authors achieve internal validity. For example, the case employees reported their perceptions of the same event: an internal promotion. This allowed the researchers to gain a clear understanding of the difference in perception by work modality and reduced the chances of internal validity problems. Yin (2018) states a single case is appropriate for a critical case, defined as "critical to your theory or theoretical propositions" (p. 49). Second, the authors felt the case was unusual because it is not typical to have access to employees in a large publicly traded company. Yin (2018) states a single-case study design is appropriate when the case is unusual.

The case data was collected from interviews, policies, documents, and informal interactions. The unit of analysis for the case was a salesperson. The research team interviewed seven MGM employees who worked directly for the president of MGM. The team included two teleworkers, three office-based employees, and two mixed employees (see Table 1). Each employee was interviewed by the same researchers over Zoom web-conferencing software. Over six hours of interviews were recorded, transcribed, and coded. The research team used NVivo coding software to code and synthesize the data. All interviews began by calibrating the definition of organizational politics and the informal system. To ensure calibration of the definition, respondents were asked to take the Fedor et al. (2008) perceptions of organizational politics validated instrument. The participant survey results were reviewed in the interview, so the researcher could validate the responses against the respondent's definition of perceptions of organizational politics. More importantly, this also allowed the researcher to calibrate the valence of the perception and clarify the actions that caused a positive or negative valence.

At the completion of interviews, researchers calibrated the coding and aligned on categories. As categories emerged, the researchers looked to current POP literature theory for valence. The Butler et al. (2019) theory for positive organizational politics fit the case study data. The research team reviewed the findings with the MGM president and the study participants to validate interpretation of the interviews.

Table 1. Interviewees

\begin{tabular}{|l|l|l|l|}
\hline Pseudonym & \multicolumn{1}{|c|}{ Position } & \multicolumn{1}{|c|}{ Work Location } & \multicolumn{1}{|c|}{ Telewk Intensity } \\
\hline Pat & President & Office-Based & n/a \\
\hline Alex & Sales Manager & Office-Based & High \\
\hline Chris & Sales Manager & Telecommuter & n/a \\
\hline Jordan & Director & Office-Based & Low \\
\hline Kennedy & Director & Mixed & n/a \\
\hline Cameron & Director & Office-Based & High \\
\hline Taylor & Sales Manager & Telecommuter & Low \\
\hline Skylar & Sales Manager & Mixed & \\
\hline
\end{tabular}


Fortune 250 company that sells products through multiple channels (retail, wholesale, and e-commerce) and continuously develops new outlets for distribution. Like many large companies, MGM has formal human resource/employee policies and procedures outlined in an employee handbook; however, MGM does not have an official teleworking policy, and a strict interpretation of the employee handbook would suggest that MGM does not permit telework.

We obtained permission to conduct the case study from the division's human resource (HR) director and the division's president. When describing our intent to uncover whether POP differences exist between office-based employees and teleworkers, the HR director snickered, "This is kind of like studying if grass is green. Of course, there is a difference in organizational politics between office-based employees and teleworkers."

The unit of analysis was a retail salesperson. The case study focused on seven sales employees who reported to the division president, Pat. Three of the volunteers were office-based employees (Alex, Cameron, and Jordan), two were purely teleworkers (Chris and Taylor), and two were mixed: part telework/part office-based employees (Kennedy and Skylar).

The MGM sales team leverages several communication platforms, which vary in levels of information richness. Information richness describes the amount of information transferred between participants including cues (e.g., vocal inflection, body gestures), immediacy of feedback, language variety, and personalization (Lo \& Lie, 2008). The team employs the following:

- Slack, a chatroom, for informal discussion

- Email for non-urgent communication

- A SharePoint site to communicate organizational changes

- Company-wide announcements and events for content to all employees, such as benefits

- WebEx for meetings requiring video or screen sharing

- Text messages for urgent communication between team members

MGM teleworkers and office-based employees use both a formal system (going through organizationally defined channels) and an informal political system to accomplish tasks. Furthermore, it is not uncommon for employees to move freely between both systems to achieve results. Both groups leveraged their network, asked favors, and went around co-workers or supervisors to achieve personal goals, which of- ten aligned with organizational interest. Jordan, an office-based employee, stated, "90\% of the time (I) just follow the normal process and then maybe 10\%, I will go the politics route." Chris ranked the use of the political system higher, saying it was "probably a 50/50 split". Taylor, another high-intensity teleworker, suggested: "(I) worked in the gray a lot, about 75$80 \%$ of the time."

Confirming that all employees were familiar with the informal political system, we investigated how each team member perceived organizational politics and discovered that employees, regardless of location, viewed the use of the political system in the same light. The MGM team members, irrespective of work location and intensity, perceived politics in the same way. Moreover, the case evidence indicated that POP could be predicted by understanding the number of beneficiaries of the act, intent (self-interest), and the level of transparency. The case was clear; a political act was most likely negatively perceived if a single individual benefited. If a team benefited, the act was most likely positive, unless there was a lack of transparency or the act involved self-interest.

Chris, a high-intensity teleworker, expressed that self-interested intent resulted in a negative perception, "when the intent is selfish and not, not necessarily to move the bigger... our goal or [help our] team along." Kennedy, a low-intensity teleworker, stated that a selfless intent is needed for a political act to be perceived as positive: "I think if people understand your actions are clearly in support of the greater whole, even if it's painful, folks will respect it. In the absence of explanation (i.e., no narrative is provided so you come up with your own), and people don't understand how actions are altruistic, they will be unhappy."

Chris explains that political acts need to benefit a group to be perceived as positive: "You need to make sure that you're not the lone wolf when you're trying to explain something or provide it just kind of an ancillary value to a company or a team. So, from that perspective, you need to build a network of people that believe in what you do and what you're trying to achieve. So, I feel like that's a positive connotation of politics. Now, where it gets a little weird is when you have teams of people that are identifying only self-interest or trying to just help move each other along in their careers versus really solve a business need or create a solution. That's where it gets a little hazy and can cause some problems." Cameron, an office-based employee, described an example where a group benefited, but the act was negatively perceived because it lacked transparency. The beneficia- 
ry group went to the board of directors instead of the process owner: "Here was a group of people that I had networked with [and] we all had ... voiced our... ideas for some new channel strategies [to a board of director meeting rather than using normal channels]. Long story short, it was viewed as like ganging up [on] people that really didn't have the authority to voice these concerns in a board meeting."

Jordan, an office-based employee, used political tactics to get a product launched after the formal system did not yield results. Jordan achieved a positive perception by ensuring a group developed the concept and the company benefited, rather than an individual: "We have a future potential feature for our widget, and it involves some cutting-edge research... I believe that it is possible, but this other person is a gatekeeper for resources to make this thing happen. So instead of going through that person, I saw a sign up that said, 'we're looking for intern projects', And I said, okay, great. This is an opportunity to do something good for the organization. Give interns a project or actionable projects that they can sink their teeth into. And at the same time, they will then prove out or at least get my project started."

The results were consistent across all types of workers--high and low-intensity teleworkers and office-based employees--a single individual benefiting was likely to be perceived negatively. When a group, or the organization benefits, it was more

likely to be viewed positively, regardless of location. To build on this concept, we discovered during the study, one event, an off-cycle promotion, was perceived negatively by all members of the case study, despite work location and telework intensity. Cameron, one of Pat's team members, received a promotion in an off-cycle process. MGM's policies address off-cycle promotions; however, practice dictates that they are rare and only given for extraordinary results. MGM selects individuals for advancement based on business and people results. The case members perceived Cameron as meeting the criteria for promotion on the people side; however, they did not feel the promotion was deserved from a business results perspective. The sales team defined business results in terms of sales revenue and knew Cameron had the lowest performance in the division. Jordan, an office-based sales director, describes the perception, "Another group in the organization, has recently promoted a couple of people and nobody at our level thinks that that was justified. [The individuals] used politics in the negative way to grow their careers."

Chris, a teleworker, described the event, "[I] struggled really hard with... I didn't feel good about it at all and feel like they worked politics to get what they wanted." Also, "[Cameron's team] hasn't actually succeeded and, and [his products aren't] profitable...So while everybody else around them is trying to grind it out and make their already profitable businesses larger and more impactful to the company... [Cameron] gets promoted with a technology that's not quite adopted. It's not fully baked yet. So, it caused the rub in a lot of different ways." At the same time, office-based Alex suggested: "It was bad for organizational culture because you feel like you were passed up on something because of who someone is, not based on actual results."

Also, the organizational practice for announcing promotions includes a statement at the team meeting followed by posting on the company SharePoint. In this example, the announcement was less transparent. Although Cameron's promotion was posted to SharePoint with other company announcements, there was no mention of it during the team meeting. As a result, the team members stumbled on the promotion announcement rather than learning directly from Pat. Alex, an office-based employee, said, "It wasn't communicated, we found out about it because it was put onto the internet. So, I think that is a gap."

The team members in the case viewed the advancement as a political act and perceived it negatively. The team members felt the promotion lacked transparency and legitimacy. In their eyes, Cameron's sales results were lower than their sales results. Therefore, both teleworkers and office-based employees perceived the act negatively. In the same manner, the teleworking intensity did not make a difference to the perception. Chris and Taylor (high-intensity teleworkers) viewed the promotion the same as Alex, an office-based employee.

The case study determined that the perception of a political event is determined by the number of beneficiaries, transparency, and intent. The case found there was no difference in the POP between teleworkers and office-based employees. Also, low-intensity teleworkers and high-intensity teleworkers perceived the promotion in the same way.

The results are summarized in Table 2.

\section{Discussion}

Based on the employee outcome differences identified in the existing teleworker literature, it was counterintuitive to find no variations in POP between teleworkers and office-based employees. Prior researchers had found that individuals engaged in 
Table 2. The Perception of the Promotion Event

\begin{tabular}{|c|c|c|c|c|c|}
\hline Pseudonym & Work Location & $\begin{array}{l}\text { Telework } \\
\text { Intensity } \\
\end{array}$ & $\begin{array}{l}\text { Perception of } \\
\text { Promotion } \\
\end{array}$ & $\begin{array}{c}\text { Rationale for } \\
\text { Perception }\end{array}$ & Notes \\
\hline Pat & Office-Based & $\mathbf{n} / \mathbf{a}$ & $\mathbf{n} / \mathbf{a}$ & $\mathrm{n} / \mathbf{a}$ & $\begin{array}{l}\text { Did not discuss } \\
\text { promotion }\end{array}$ \\
\hline Alex & Office-Based & $\mathbf{n} / \mathbf{a}$ & Negative & $\begin{array}{l}\text { Lack of transpar- } \\
\text { ency }\end{array}$ & \\
\hline Chris & Telecommuter & High & \begin{tabular}{|l|} 
Negative \\
\end{tabular} & Few beneficiaries & \\
\hline Jordan & Office-Based & $\mathbf{n} / \mathbf{a}$ & \begin{tabular}{|l|} 
Negative \\
\end{tabular} & Few beneficiaries & \\
\hline Kennedy & Mixed & Low & \begin{tabular}{|l|} 
Negative \\
\end{tabular} & Few beneficiaries & \\
\hline Cameron & Office-Based & $\mathbf{n} / \mathbf{a}$ & $\mathbf{n} / \mathbf{a}$ & $\mathbf{n} / \mathbf{a}$ & $\begin{array}{l}\text { Did not discuss } \\
\text { promotion }\end{array}$ \\
\hline Taylor & Telecommuter & High & Negative & $\begin{array}{l}\text { Lack of transpar- } \\
\text { ency }\end{array}$ & \\
\hline Skylar & Mixed & Low & $n / a$ & n/a & $\begin{array}{l}\text { Did not discuss } \\
\text { promotion }\end{array}$ \\
\hline
\end{tabular}

high-intensity telework experience professional isolation, have reduced knowledge transfer, and miss situational context (Gajendran \& Harrison, 2007; Golden, 2007; Golden et al., 2008); therefore, it is reasonable to predict that a teleworker with less access to face-to-face interactions may interpret and perceive events differently.

However, turning to POP literature, this finding is less of a surprise and aligns with the Butler et al. (2019) model, which posits that higher numbers of beneficiaries and more transparency lead to a positive POP and vice versa. In this case study, the political act benefited an individual rather than a group, and it lacked transparency; therefore, the sales team members perceived it as negative, regardless of their primary work location.

The data from the case indicate that there is not a difference between teleworkers and office-based employees in the perception of organizational politics. The absence of difference is a novel finding in the organizational politics literature, which focuses on office-based employees. Future research can explore many areas. While this is a case, based in the specific context of MGM, it would be interesting to conduct a broader study to see if the case results could be generalized among a larger population. Does the perception of organizational politics differ by work location in companies outside of MGM? In the same vein, our case was grounded in a sales organization that we feel may have a bias toward the informal system. Sales roles typically target individuals with strengths in the area of building networks and relationships, which could protect them against the personal isolation and loss of context felt by other teleworkers. Future research should consider a broader sample of teleworkers and office-based employees, consisting of several functions (e.g., Finance, IT) to extend the understanding of potential POP differences.

\section{Conclusion}

We found that in the context of MGM, there was no difference in POP between office-based employees and teleworkers. Both sets of employees shared the same negative perception of the use of organizational politics for an out of cycle promotion. Furthermore, both the office-based employees and the teleworkers cited the same criteria to explain their perceptions. This finding gives further support to the Butler et al. (2019) model, that regardless of work location, the number of beneficiaries and the level of transparency ultimately determine how the act will be perceived.

This study answers calls from organizational politics researchers for exploration in the world of teleworkers. This finding also informs employees that regardless of work location, a balance of altruism and transparency is required to achieve positive POP. Finally, this discovery also advises managers and human resource leaders to ensure they can properly educate their workforce to obtain the best outcomes.

\section{References}

Apgar IV, M. (1998). The alternative workplace: Changing where and how people work. Harvard Business Review, 76(3), 121-137.

Bélanger, F., Watson-Manheim, M. B., \& Swan, B. R. (2013). A multi-level socio-technical systems telecommuting framework. Behaviour \& Information Technology, 32(12), 1257-1279. https://doi. org/10.1080/0144929X.2012.705894 
Bloom, N., Liang, J., Roberts, J., \& Ying, Z. J. (2014). Does working from home work? Evidence from a Chinese experiment. The Quarterly Journal of Economics, 130(1), 165-218. https://doi.org/10.1093/ qje/qju032

Boell, S. K., Cecez-Kecmanovic, D., \& Campbell, J. (2016). Telework paradoxes and practices: the importance of the nature of work. New technology, work and employment, 31(2), 114-131. https://doi. org/10.1111/ntwe.12063

Breaugh, J. A., \& Farabee, A. M. (2012). Telecommuting and flexible work hours: Alternative work arrangements that can improve the quality of work life. In Work and quality of life (pp. 251274): Springer. https://doi.org/10.1007/978-94007-4059-4_14

Butler, W., Decker, G., Peters, J., Thomas, A., \& Merritt, S. (2019). Positive organizational politics: A grounded theory study. Available at SSRN 3468162. https://doi.org/10.2139/ssrn.3454066

Cooper, C. D., \& Kurland, N. B. (2002). Telecommuting, professional isolation, and employee development in public and private organizations. Journal of Organizational Behavior: The International Journal of Industrial, Occupational and Organizational Psychology and Behavior, 23(4), 511532. https://doi.org/10.1002/job.145

Cropanzano, R., Howes, J. C., Grandey, A. A., \& Toth, P. (1997). The relationship of organizational politics and support to work behaviors, attitudes, and stress. Journal of Organizational Behavior: The International Journal of Industrial, Occupational and Organizational Psychology and Behavior, 18(2), 159-180. https://doi.org/10.1002/ (SICI) 1099-1379(199703)18:2<159::AIDJOB795>3.0.CO;2-D

Elron, E., \& Vigoda-Gadot, E. (2006). Influence and political processes in cyberspace: The case of global virtual teams. International Journal of Cross Cultural Management, 6(3), 295-317. https://doi. org/10.1177/1470595806070636

Fay, M. J., \& Kline, S. L. (2011). Coworker relationships and informal communication in high-intensity telecommuting. Journal of Applied Communication Research, 39(2), 144-163. https://doi. org/10.1080/00909882.2011.556136

Fedor, D., Maslyn, J., Farmer, S., \& Bettenhausen, K. (2008). The contribution of positive politics to the prediction of employee reactions. Journal of Applied Social Psychology, 38(1), 76-96. https://doi. org/10.1111/j.1559-1816.2008.00297.x

Felstead, A., Jewson, N., Phizacklea, A., \& Walters, S. (2002). Opportunities to work at home in the context of work-life balance. Human resource management journal, 12(1), 54-76. https://doi. org/10.1111/j.1748-8583.2002.tb00057.x

Ferris, G. R., Ellen III, B. P., McAllister, C. P., \& Maher, L. P. (2019). Reorganizing organizational politics research: A review of the literature and identification of future research directions. Annual Review of Organizational Psychology and Organizational Behavior, 6, 299-323.

Ferris, J. P., Ertem, G., \& Agarwal, V. (1989). Mineral catalysis of the formation of dimers of 5'-AMP in aqueous solution: the possible role of montmorillonite clays in the prebiotic synthesis of RNA. Origins of Life and Evolution of the Biosphere, 19(2), 165-178. https://doi.org/10.1146/annurev-orgpsych-012218-015221

Gajendran, R. S., \& Harrison, D. A. (2007). The good, the bad, and the unknown about telecommuting: Meta-analysis of psychological mediators and individual consequences. Journal of Applied Psychology, 92(6), 1524. https://doi. org/10.1177/0018726707084303

Gallup. (2016). The state of the American workplace. Gallup. https://www.gallup.com/workplace/238085/state-american-workplace-report-2017.aspx

Golden. (2007). Co-workers who telework and the impact on those in the office: Understanding the implications of virtual work for co-worker satisfaction and turnover intentions. $\mathrm{Hu}$ man Relations, 60(11), 1641-1667. https://doi. org/10.1177/0018726707084303

Golden, Veiga, \& Dino. (2008). The impact of professional isolation on teleworker job performance and turnover intentions: Does time spent teleworking, interacting face-to-face, or having access to communication-enhancing technology matter? Journal of Applied Psychology, 93(6), 1412. https://doi.org/10.1037/a0012722

Gorman, K. (2017, October 12). Why IBM brought remote workers back to the office--And why your company might be next. Forbes. https://www. forbes.com/sites/carolkinseygoman/2017/10/12/ why-ibm-brought-remote-workers-back-to-theoffice-and-why-your-company-might-be-nex$\mathrm{t} / \# 5 \mathrm{e} 25708716 \mathrm{da}$

Harker Martin, B., \& MacDonnell, R. (2012). Is telework effective for organizations? A meta-analysis of empirical research on perceptions of telework and organizational outcomes. Management Research Review, 35(7), 602-616. https://doi. org/10.1108/01409171211238820

Kacmar, K. M., \& Ferris, G. R. (1991). Perceptions of organizational politics scale (POPS): Development and construct validation. Educational 
and Psychological Measurement, 51(1), 193-205. https://doi.org/10.1177/0013164491511019

Kaplan, S., Engelsted, L., Lei, X., \& Lockwood, K. (2018). Unpackaging manager mistrust in allowing telework: Comparing and integrating theoretical perspectives. Journal of business and psychology, 33(3), 365-382. https://doi.org/10.1007/ s10869-017-9498-5

Lo, S.-K., \& Lie, T. (2008). Selection of communication technologies--A perspective based on information richness theory and trust. Technovation, 28(3), 146-153. https://doi.org/10.1016/j.technovation.2007.05.017

Miller, C. C., \& Rampell, C. (2013). Yahoo orders home workers back to the office. The New York Times, 25.

Mintzberg, H. (1985). The organization as political arena. Journal of management studies, 22(2), 133154. https://doi.org/10.1111/j.1467-6486.1985. tb00069.x

Myers, M. D. (2019). Qualitative research in business and management: Sage Publications Limited.
Taskin, L., \& Bridoux, F. (2010). Telework: a challenge to knowledge transfer in organizations. The International Journal of Human Resource Management, 21(13), 2503-2520. https://doi.org/10.1080/ 09585192.2010 .516600

Turetken, O., Jain, A., Quesenberry, B., \& Ngwenyama, O. (2010). An empirical investigation of the impact of individual and work characteristics on telecommuting success. IEEE Transactions on professional communication, 54(1), 56-67. https:// doi.org/10.1109/TPC.2010.2041387

Yin, R. K. (2018). Case study research and applications. Design and Methods, 6.

\section{Review}

This article was accepted under the strict peer review option. For futher details, see the descriptions at:

http://mumabusinessreview.org/peer-review-options/

\section{Authors}

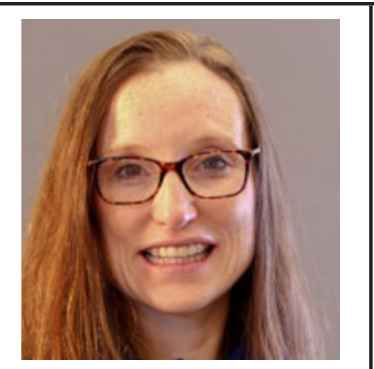

Gretchen Decker has worked for PepsiCo in the Frito-Lay division for over fifteen years. She currently serves as the Director of Strategy and Transformation for Frito-Lay North America in Plano, TX. Prior to her role in strategy, she was a Finance Director for the Frito-Lay Northwest Division. She also served in several supply chain roles in Frito-Lay in Hawaii, California, and TX. Prior to PepsiCo, Gretchen served in the U.S Army as a Medical Service officer and Civil Affairs officer. Gretchen holds a Master of Business Administration (MBA) degree from the University of Hawaii and earned a Bachelor of Science in Chemistry from Lincoln University.

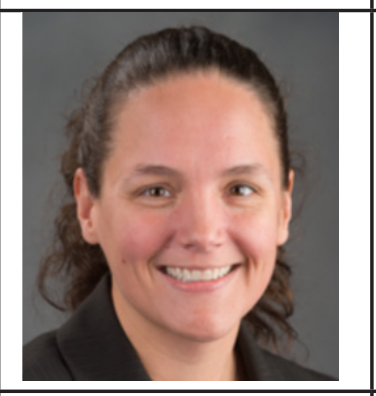

Jaime Peters is an Assistant Professor of Finance at Illinois Wesleyan University. Prior to becoming an academic, Jaime was a Senior Analyst for Morningstar, Inc., specializing in banks. During her time at Morningstar, she was the lead analyst on most of the major banks in the US, including through the 2008 crisis. Jaime appeared regularly in print and TV during this time trying to explain the stock market's reaction to the housing crisis. Prior to working at Morningstar, Jaime was a Stock Analyst at State Farm Insurance Company. During her tenure at State Farm, Jaime earned her CPA and CFA Charter, as well as her MBA at the University of Chicago.

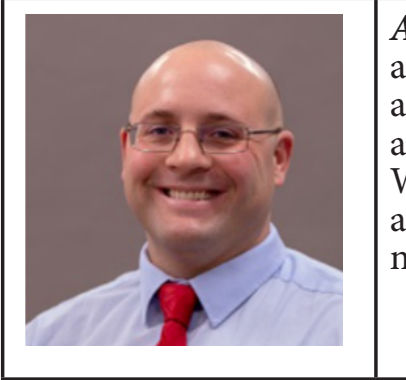

Andrew Thomas currently works in the Business and Accounting Department at Carroll College, Helena, Montana. He holds both a Juris Doctorate degree and a Master's degree in Accounting from Gonzaga University, as well as a Doctorate degree in Political Behavior, Public Policy and Public Administration from Washington State University. He is a member of the Idaho State Bar. His research and teaching interests include taxation, accounting, law, public policy, management and organizational behavior. 


\begin{tabular}{|l|l|}
\hline & $\begin{array}{l}\text { Elizabeth Boyle works in Strategy at Mallinckrodt Pharmaceuticals and has } \\
\text { served as an adjunct faculty member at Lindenwood University since 2012 and } \\
\text { the University of Missouri-St. Louis since 2020. She has previously held roles } \\
\text { in Internal Audit and Tax. Elizabeth holds an Executive Master of International } \\
\text { Business from Saint Louis University and a Bachelor of Arts in Accounting de- } \\
\text { gree. She is a Certified Public Accountant (CPA) and Certified Internal Auditor } \\
\text { (CIA). }\end{array}$ \\
\hline & $\begin{array}{l}\text { William (Bill) Butler is Vice President of Engineering for White-Rodgers, a busi- } \\
\text { ness unit of Emerson Commercial \& Residential Solutions. He holds a Master } \\
\text { of Business Administration (MBA) degree from Washington University and a } \\
\text { Master of Science degree in Electrical Engineering from Purdue University. Bill } \\
\text { is a technology executive experienced in leading cross functional technical teams } \\
\text { to solve tough problems. He particularly enjoys bringing new solutions or inno- } \\
\text { vative technologies to market. }\end{array}$ \\
\hline
\end{tabular}

